\title{
Social Security Reform and Personal Saving: Evidence from Brazil
}

\author{
Pedro Tonon Zuanazzi ${ }^{1}$, Adelar Fochezatto ${ }^{2,3} \&$ Marcos Vinicio Wink Júnior ${ }^{4}$ \\ ${ }^{1}$ Economics and Statistics Foundation (FEE), Porto Alegre, Brazil \\ ${ }^{2}$ Pontifical Catholic University of Rio Grande do Sul (PUCRS), Porto Alegre, Brazil \\ ${ }^{3}$ Researcher for National Council for Scientific and Technological Development (Conselho Nacional de \\ Desenvolvimento Científico e Tecnológico - CNPq), Brazil \\ ${ }^{4}$ Department of Economics, Santa Catarina State University (UDESC), Florianópolis, Brazil \\ Correspondence: Marcos Vinicio Wink Junior, Department of Economics, State University of Santa Catarina, \\ 2007 Madre Benvenuta St., Florianópolis - SC, Zip Code: 88.035-901, Brazil. Tel. 5548-3664-8200. E-mail: \\ marcos.winkjunior@udesc.br
}

Received: July 4, 2018

Accepted: July 26, 2018

Online Published: August 10, 2018

doi:10.5539/ijef.v10n9p26

URL: https://doi.org/10.5539/ijef.v10n9p26

\begin{abstract}
The population aging process has caused a financial imbalance in the social security systems of countries based on pay as you go system, as is the case in Brazil. To face this challenge, the Brazilian governments have undertaken several reforms since the 1988 Constitution. Confronting the life cycle hypothesis, the aim of this paper is to estimate the causal effects of Social Security Reforms on the Likelihood of Saving in Brazil by exploring two exogenous events, the 41th (of 2003) and 47th (of 2005) Constitutional Amendments, that reduced the expectations of benefits only for public servants. Using data from the House Budget Surveys, the results of differences-in-differences models show that the reform increased in a range of 2.1 to 2.9 percentage points in the probability of saving of the treated group. The results are in line with the recent literature indicating that reforms contribute to an increase in personal savings.
\end{abstract}

Keywords: social security reform, personal savings, life cycle

\section{Introduction}

Population aging makes public retirement and pension plans excessively burdensome, thus motivating reformist ideas in many countries (Mackenzie et al., 1997). Due to the demographic transition, changes in the social security system - whether through reforms or only partial changes in the legislation - have gained worldwide interest, particularly after the privatization of the Chilean pension funds (Samwick, 2000).

While many public managers opted for reforms that would maintain the format of their pension systems, only modifying the retirement age or reducing benefit amounts, others made extensive modifications, implementing capitalization plans - with defined contributions - instead of simple distribution plans with defined benefits. In any case, the fiscal effects of these changes as well as their macroeconomic impacts - particularly on the rate of savings - has begun to be discussed.

Economic theory generally portrays families' decisions to save as fundamentally intertemporal choices, based on the life cycle (Modigliani \& Ando, 1957); (Ando \& Modigliani, 1963) and permanent income (Friedman, 1957) hypotheses, whose outcomes are that individuals pursue a consumption profile compatible with their gains throughout their lifetimes. Thus, the reduction in the expectation of future income could reduce consumption in the present and consequently increase savings.

The logic would be that, in the systems of defined benefits, individuals would be less likely to save during their working life, given the expectation of receiving the public pension when they age, particularly in countries where this benefit is given integrally. In contrast, in systems in which individuals cannot rely on public pensions or if this amount were limited to a ceiling, then there would be a need to save in advance, in order to maintain the consumption standard in retirement, in accordance with the life cycle theory.

However, there is no consensus in the literature about the relationship between pension wealth (Note 1) and the wealth from financial assets. According to Gale (1998), this is due to some existing ambiguities. Among them, the author cites that pension wealth and the wealth accumulated in financial assets are not totally substitutable 
assets because (i) pension wealth does not have liquidity, which means that individuals whose consumption is close to their budget constraints cannot utilize it; (ii) individuals also save for reasons other than just retirement, in which case the pension wealth cannot be used; and (iii) individuals do not necessarily make the mental association that they are substitutable assets. Attanasio and Brugiavini (2003) add to this the different rates of income between pension wealth and the wealth from financial assets.

Given the aforementioned theoretical ambiguity, the importance of empirical studies that seek to relate the impacts - caused by the changes in social security rules - on household savings increases. Thus, in the Brazilian context, the social security reform that occurred between 2003 and 2005 is an important case study. The functioning of the Brazilian social security system is different for three groups of workers: public servants, military employees (of the Federal Union, the States, the Federal District (FD), and the Territories), and other salaried individuals (employees of private companies, professionals, self-employed people, microentrepreneurs, and others). While the latter are legally bound to the General Social Security System - GSSS (Regime Geral de Previdência Social - RGPS), administered by the National Social Security Institute (Instituto Nacional do Seguro Social - INSS), civil servants and military employees have their retirement directly linked to the Specific Social Security Systems - SSSS (Regimes Próprios de Previdência Social - RPPS) of the respective public agencies (Note 2). However, the major differences are in the characteristics of the contributions and the benefits.

While historically in the GSSS one contributes with a percentage of income or of the ceiling, with the benefits being limited to this ceiling, in the public service, the contributions and the benefits have been very different over time. The Federal Constitution (Constituição Federal - CF) of 1988 included periods of unemployment as extensions of the working period, paying the entire salary that the person received in the last month before retirement and not requiring contributions during the unemployed phase.

Since then, several modifications have been made to the Brazilian social security system, most notably through the 20th (of 1998), 41th (2003) and 47th (2005) Amendments of the Brazilian Constitution. The last two, in particular, specifically affected public civil servants, who had their expectations of retirement benefits reduced, without, however, substantial changes to the systems of the military employees and those covered by the GSSS.

Based on this context, this present study aims to verify whether the changes made by the reform of 41th and 47th Constitutional Amendments - which changed the expectations of benefits in the retirement of public servants had positive effects on the likelihood of these workers saving, having as control groups the military employees and GSSS-linked workers. For this, a differences-in-differences model was used with the microdata of the House Budget Surveys - HBS of 2002-2003 and 2008-2009. The study of the Brazilian case is particularly relevant because in addition to being a developing country, further reforms are expected over the next few years.

It is also worth noting that throughout recent Brazilian history, several social security reforms have been utilized, which, in some way, represent advances. However, if the current rules are maintained, the projections for the Brazilian social security system are worrisome because maintaining the average historical growths in labor productivity and the real value of the benefits, the cost scenario becomes unsustainable (de Mesquita \& Neto, 2013). Therefore, new reforms should be enacted, which makes it essential to discuss both their fiscal effects and their macroeconomic impacts.

Following this introduction, Section two presents the literature review, Section three reviews the Brazilian social security system and its modifications, Section four explains the methodology adopted, Section five presents the results obtained, and, finally, the conclusions are highlighted in Section six.

\section{Literature Review}

Feldstein (1974) was one of the first studies to relate social security coverage to private savings. Based on the life cycle hypothesis, the author states that in state-run social security systems, individuals expect to receive high future benefits and, therefore, will tend to decrease their savings in the present.

For the American case, Feldstein (1974) estimated - through a time series model - a consumption function using - in addition to current income and financial wealth - an aggregated estimate of the pension wealth of families. The three coefficients were significant, which led the author to conclude that the social security system would reduce private savings by between 30\% and 50\%. Similar results were found by Munnell (1974), who estimated that social security would have a significant negative impact on private savings.

The Chilean social security reform in 1981, which changed it from a simple distribution system to a capitalization system, was the result of several studies. Haindl Rondanelli (1996) stated that the reform was responsible for an increase in savings of approximately 6.6 of the Chilean GDP. The results of Schmidt-Hebbel et al. (1998) suggest that the Chilean reform improved the labor market performance and increased savings, 
investment, and productivity, thus contributing to a quarter of the increase in the country's growth. According to Holzmann (1997), the transition from a simple distribution system to a capitalization format has a strong fiscal impact shortly after implementation because the government loses the income from contributions but maintains payments to those already retired under the previous system. However, with fiscal surpluses in earlier years, as was the case of the Chilean pension reform, this impact may be reduced.

The above results are in line with a report by Serageldin et al., who proposed profound reforms in social security systems in both developing and developed economies. The report proposed a model based entirely on capitalization, with it being mandatory and, preferably, private. The report suggests that these proposed reforms would not only be beneficial to retirees and pensioners but would also simultaneously increase savings and encourage capital formation and economic development.

Samwick (2000), however, analyzed the effect of social security on aggregated savings using panel data for countries for 25 years, the results of which indicate that there was weak evidence that the implementation of reforms with defined contributions would change the savings rates of the respective countries. However, those with a simple distribution system would tend to have lower savings rates, and this effect would increase with a higher coverage rate of their pension systems. Bosworth and Burtless (2004) found evidence that in the capitalization model, pension savings only replace private savings, with no greater gains in national savings.

As for the use of microdata to answer this question, some studies have already been done; for example, Munnell (1976), King and Dicks-Mireaux (1982), Hubbard (1986), Brugiavini (1987), and Jappelli (1995). However, it is in more recent studies that the differences-in-differences methodology has come to be used, the results of which have been that the reduction in pension wealth has a positive impact on savings. In this case, the works of Attanasio and Brugiavini (2003), Bottazzi et al. (2006), Sandoval-Hernandez (2012), Lachowska and Myck (2015), and Yang (2016) are notable.

Attanasio and Brugiavini (2003) made use of public surveys done before and after the Italian social security reform, which occurred in 1992 but was projected to be fully implemented only in 2032. In this study, the authors explored the transition rules that attenuate the changes imposed on the individuals about to retire, adopting them as a control group. Their results indicate that, in general, the reduction in the expectation of benefits positively affects the savings of Italian workers. The effects are even stronger for the youngest, who are affected the most by the reform.

Bottazzi et al. (2006) is also relevant to the Italian case; however, they investigated not only the 1992 reform but also the reforms of 1995 and 1997. Unlike Attanasio and Brugiavini (2003), who estimated the pension wealth of individuals, the authors made use of questions that enabled working with the perception of pension wealth, through subjective information about the individuals. Their control groups are the oldest workers in the private sector not affected by the reforms. Their results indicate that the difference in compensation between pension wealth and private wealth is approximately $30 \%$, being much greater, however, for the workers who have knowledge about their social security benefits.

Sandoval-Hernandez (2012), in turn, studied the effects of the reform that occurred in Mexico in 1997, which, like the Chilean case, went from a simple distribution model to a capitalization model - as a control group, public service workers not included in the reform were used. The estimates indicated there was a large increase in the savings rates of the workers affected by the reform.

Lachowska and Myck (2015) analyzed the Polish social security reform of 1999, which affected the elderly cohorts differently. The authors found that the coverage of the public pension reduces private savings. These effects would be stronger among people with a high level of education who would understand public wealth and private wealth as substitutable assets. Yang (2016) explored the social security reform that occurred in Taiwan in 2005, using families from the public sector as a control group. These results showed that there was a significant reduction in the private savings rate of families.

\section{The Brazilian Social Security System and Its Modifications between the Federal Constitution (FC) of 1988 and the Collection of the HBSs of 2008-2009}

In the 1988 Federal Constitution, the simple distribution model that had been used in the Brazilian social security system in previous decades was maintained; however, a set of general rules more generous to workers was implemented (Giambiagi \& de Além, 2008).

With the FC of 1988 coming into effect, four rules were applied for retiring under the GSSS, and there was a fifth rule for the SSSS. The rules are (a) voluntary by age (65 years for men and 60 years for women, with a reduction of 5 years for rural workers); (b) voluntary by length of service (35 years of service for men and 30 
years for women, with a reduction of 5 years for teachers); (c) voluntary proportionally for length of service (30 years for men and 25 years for women); (d) for permanent disability; and (e) compulsory by age at seventy (only for SSSS).

However, many differences existed between the SSSS and GSSS. Among them, public servants - in addition to not contributing to social security (they began to contribute only from the $3^{\text {rd }}$ Constitutional Amendment of 1993 onward) - entered into inactivity with full benefits. In addition to making monthly contributions, the workers linked to the GSSS had their pensions based on the average of the last 36 contributions, but limited to the ceiling of the GSSS.

The first social security reform that occurred in Brazil after the Constitution of 1988 was implemented by the $20^{\text {th }}$ Constitutional Amendment of 1998, which formally established the contributory nature of the social security, seeking the need for an actuarial and financial balance. Although the intention was to unify the pension systems of all workers (including the military), the reform ended up making much smaller changes than those originally planned (Giambiagi \& de Além, 2008).

Thus, for the SSSS of the civil servants, the $20^{\text {th }}$ Constitutional Amendment imposed a minimum age for full retirement by period of contribution (60 years of age for men and 55 for women); stipulated a minimum period of service and occupancy in the position; and made it impossible to accumulate benefits, disallowing public servants who were inactive to increase their income. These rules did not affect the public servants who would already have been entitled to retire before their implementation, while for the active public servants who were not entitled, a transition rule was created (Note 3).

In the case of the GSSS, the $20^{\text {th }}$ Amendment deconstitutionalized the calculation rule for retirement, allowing the changes, from that moment forward, to occur by ordinary law. Thus, in the following year, through Law no. 9.876, the pension factor was created, which reduced the retirement amount depending on the contribution period and the contributor's expectation of living beyond the life expectancy. Thus, those at retirement age could choose either to have a lower benefit or to contribute for a longer time until they were entitled to the full benefit (limited to the ceiling of the GSSS). Additionally, its base value went from being the last 36 salaries to the average of $80 \%$ of the highest salaries calculated between July 1994 and the time of retirement, thus reducing the benefits of the taxpayers who had an upward income trajectory during their working life. However, for its political implementation, it was necessary to create a gradual transition rule for the pensions that would occur in the next 60 months, in addition to negotiating a bonus of 5 years in the contribution time for women and 10 and 5 years for female and male teachers, respectively, excluding university education.

Public servants of the military branch (members of the Armed Forces, military police, and military fire brigades) were not affected by any alteration of the $20^{\text {th }}$ CA. Only in 2001, through Provisional Measure no. 2.215-10 which altered Law 3.765 - did the SSSS of the military employees of the armed forces change, when contributions of $7.5 \%$ of the salary for the financing of pensions (compared to the previous contribution of 1\%) came into effect. Additionally, the Provisional Measure abolished the existing rights to a pension for unmarried military daughters, regardless of age, limiting it to children up to 21 years of age (24 years in the case of students). As for the military employees of the states (police and firemen), they were subject to the State laws, which underwent modifications in the subsequent years, with this being reflected in Provisional Measure 2.215-10.

Unlike the $20^{\text {th }}$ Amendment, the $41^{\text {th }}$ Constitutional Amendment of December 2003 affected essentially public civil servants, and it concerned the following points: (i) pensions came to be calculated based on the history of the contributions, no longer being the total of the last salary; (ii) for the amounts that exceeded the ceiling of the GSSS, pensions were limited to 70\%; (iii) the parity of adjustments between active and non-active individuals were eliminated (pensions began to be adjusted for inflation); (iv) contributions for inactive individuals also came to be levied $-11 \%$ for amounts exceeding the ceiling of the GSSS (including for those who were already retired before the $41^{\text {th }} \mathrm{CA}$ ); (v) ceilings were stipulated for the maximum limits of remuneration in all the areas (formerly this occurred for the Union only); and (vi) to encourage the voluntary delay in retirement, public servants were given the option of the permanence allowance, until the advent of compulsory retirement (70 years).

In turn, the $41^{\text {th }}$ Amendment made military employees subject to the remuneratory ceiling (and to the sub-ceilings) of the public sector. In addition, in the case of the GSSS, the impacts of the $41^{\text {th }}$ CA were minimal the only notable one being the increase in the ceiling of benefits and contributions to $R \$ 2,400.00$, in order to restore the amount equivalent to ten minimum wages from the time of the approval of the $20^{\text {th }} \mathrm{CA}$. Therefore, the main measures only affected public servants, being much more severe than those applied in the $20^{\text {th }}$ Amendment 


\section{(MENEGUIN and AMARO).}

However, the $47^{\text {th }}$ Constitutional Amendment of 2005 - also known as "parallel Constitutional Amendment Project" because it was the result of an agreement between the Government and the Congress - aimed to soften some of the rigors caused by the $41^{\text {th }} \mathrm{CA}$ to the retirement of public civil servants. Thus, for those in activity until the publication of the $41^{\text {th }}$ Amendment, it resumed the parity between active and inactive public servants that had been suppressed. For those who had entered into the public service before the $20^{\text {th }}$ Amendment of 1998 , the $47^{\text {th }}$ Amendment allowed retirement before the minimum age (65 years for men and 60 years for women) for those who cumulatively had reached (i) 35 and 30 years of contribution for men and women, respectively; (ii) more than 25 years in the public service; (iii) more than 15 years of career; and (iv) more than 5 years in the position. In this case, one could deduct one year for each year of service worked beyond the contribution time of 35 and 30 years for men and women, respectively. In other words, this rule stipulated that for those who entered prior to 1998, the sum between the contribution time and the age was 85 years for women and 95 years for men, provided they met the requirements listed above.

However, although the $47^{\text {th }}$ Constitutional Amendment had softened out some $41^{\text {th }}$ Amendment's points, it is important to note that the two amendments collectively reduced the expectation of entitlement of all the active public servants, to a greater or lesser degree, and those who were most affected were those who entered after 1998 , followed by those who entered the public service at a young age.

\section{Methodology}

Figure 1 shows the chronological order of the main changes in the Brazilian social security legislation since the Federal Constitution of 1988 as well as indicates the moments in which the House Budget Surveys (HBS) of 2002-2003 and 2008-2009 were administered to the interviewees.

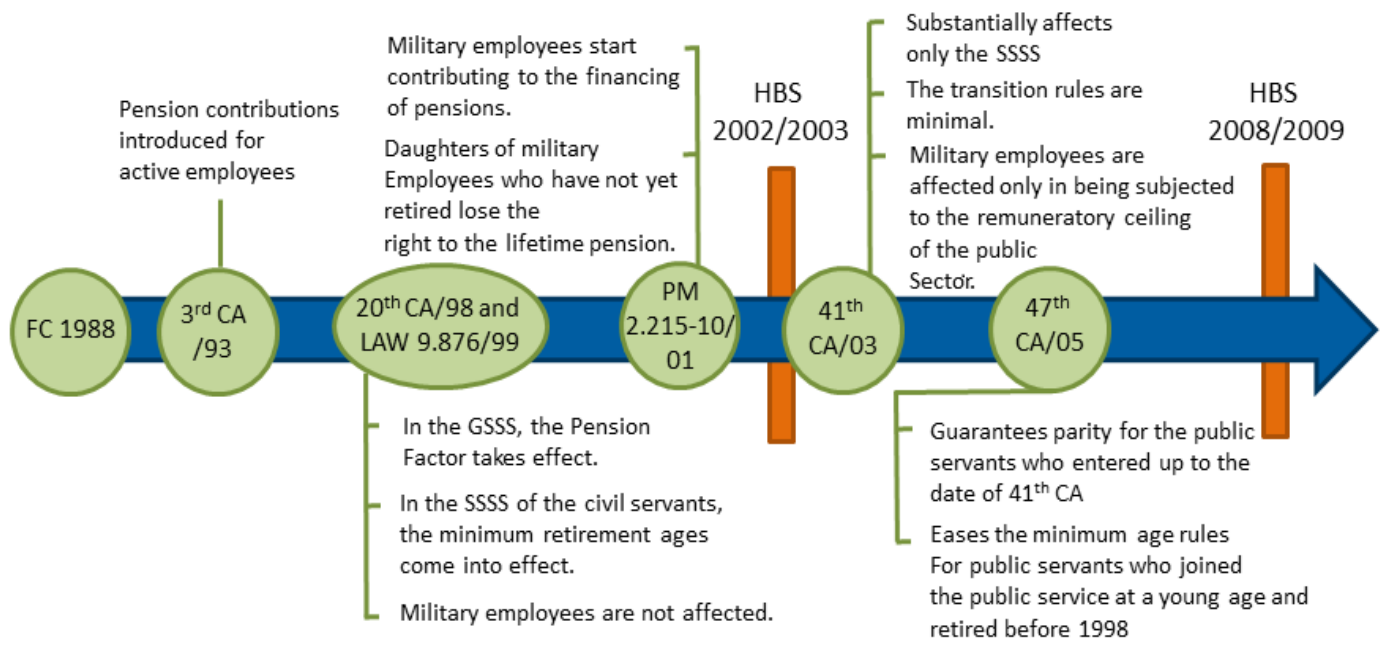

Figure 1. Chronological order of the main changes in Brazilian social security legislation since the Federal

Constitution (FC) of 1988 as well as the collection periods of the HBSs of 2002-2003 and 2008-2009

Source: Developed by the authors.

As seen, the $41^{\text {th }}$ and $47^{\text {th }}$ Constitutional Amendments occurred between the 2002-2003 and 2008-2009 HBSs (Note 4), and their combined effects led, essentially, to reductions in the public civil servants' expectations of future benefits. However, these amendments had minor impacts on the military employees and on the workers linked to the GSSS, minimally affecting a small group of these workers.

Thus, a differences-in-differences model was used, comparing the group treated and control group before and after the reform. The objective was to verify whether the changes in the social security rules of the public civil servants (treated group) influenced their likelihood of saving, comparing that - in separate scenarios - with five categories of groups not treated: military employees; employers or self-employed; employees of private companies; other groups not treated (Note 5); and, finally, all of the groups not treated combined.

The adopted methodology is propitious because, according to Cameron and Trivedi (2005), the differences-in-differences models are appropriate for measuring the effects of a treatment, such as a public policy, when information is available for the group treated and the group not treated for two periods, before and after the treatment. 
Thus, analyzing the treatment effect of the reform covered by the $41^{\text {th }}$ and $47^{\text {th }}$ Constitutional Amendments, for each period $t$, let $S P C_{i t}=1$ if the individual is a public civil servant and $S P C_{i t}=0$ if among the other workers, and let $P_{t}=0$ be the identification for the period 2002/2003 and $P_{t}=1$ be the identification for the period 2008/2009. Thus, the differences-in-differences model can be obtained by:

$$
y_{i}=\beta_{0}+\beta_{1} S P C_{i t}+\delta_{0} P_{t}+\delta_{1} S P C_{i t} P_{t}+\beta_{2} S E_{i t}+\beta_{3} E D_{i t}+\beta_{1} D E M_{i t}+\mu_{i t},
$$

in which $y_{i}$ is a binary variable (Note 6) that assumes a value of 1 for the individuals who have saved in the last 12 months and 0 for the individuals who have not saved, and $S E_{i}, E D_{i}$ and $D E M_{i}$ represent control variables of socioeconomic, educational, and demographic characteristics, respectively, with the above equation being estimated by a logit model (Note 7). Thus, $\delta 1$ is the coefficient of interest, considering that, in accordance with equations 2, 3, and 4, a transformation in its estimation returns the treatment effect generated by the changes made by the reform.

$$
\begin{aligned}
& \widehat{P r o b}_{l t}= \frac{e^{\widehat{\beta}_{0}+\widehat{\beta}_{1} S P C_{i t}+\widehat{\delta}_{0} P_{t}+\widehat{\delta}_{1} S P C_{i t} P_{t}+\widehat{\beta}_{2} S E_{i t}+\widehat{\beta}_{3} E D_{i t}+\widehat{\beta}_{1} D E M_{i t}}}{1+e^{\widehat{\beta}_{0}+\widehat{\beta}_{1} S P C_{i t}+\hat{\delta}_{0} P_{t}+\widehat{\delta}_{1} S P C_{i t} P_{t}+\widehat{\beta}_{2} S E_{i t}+\widehat{\beta}_{3} E D_{i t}+\widehat{\beta}_{1} D E M_{i t}}}, \\
& \widehat{E M_{k}}=\frac{\partial y}{\partial x_{k}}=\hat{\beta}_{k} \cdot \widehat{\operatorname{Prob}} \cdot(1-\widehat{\operatorname{Prob}}), \\
& \widehat{E T}=\hat{\delta}_{1} \cdot \widehat{\operatorname{Prob}} \cdot(1-\widehat{\operatorname{Prob}}),
\end{aligned}
$$

in which $\widehat{\operatorname{Prob}}_{l t}$ is the estimated probability of an individual i being a saver in the period $t$; $\widehat{\operatorname{Prob}}$ is the estimated probability for an individual who has all the independent variables at their respective means; $\overline{E M_{k}}$ is the estimated marginal effect that a change in the variable xk exerts on the probability of saving, given all the other independent variables at their mean values; and $\widehat{E T}$ is the estimated treatment effect, given by the marginal effect of the interaction between the dummy that identifies the treated group $\left(S P C_{i t}\right)$ and the dummy that identifies the period $P_{t}$.

However, the aforementioned interpretations are correct only if the identification hypothesis of the differences-in-differences model is maintained, which postulates that the mean change in the control group represents the counterfactual change in the treatment group if there were no treatment. That is, the model assumes that the only justification for the increase in the difference in the saving probabilities between the treated and untreated groups is due to the changes in the social security rules; otherwise, the estimated model would be biased.

Regarding the dependent variable, which identifies whether the individual is a saver, it is important to note that the economic definition of savings is given by the difference between income and consumption. However, for the use of this concept through the HBS, it is difficult to identify the savings of each individual because part of the consumption is household consumption, which makes it impossible to calculate the savings of each family member. To overcome this problem, some studies work with the measurement unit at the household level, using the attributes of the head of the family to characterize the household (Attanasio \& Brugiavini, 2003; Bottazzi et al., 2006; Sandoval-Hernandez, 2012; Lachowska \& Myck, 2015; Yang, 2016).

In this present study, however, use was made of questions available in the HBS that, at the individual level, identify the financial investments and withdrawals, for example, savings accounts, fixed income funds, bank deposit certificates, stocks, and private pensions. Thus, it is assumed that savers are those who have made investments with amounts larger than their withdrawals. With this procedure, one has the advantage of working with the exact characteristics of each person, without having to assume that the attributes of the head of the family are valid for the other members.

Thus, through the use of the microdata of the HBSs of 2002-2003 and 2008-2009, all the investments and withdrawals of each individual $i$ in the last 12 months were verified, with their financial balance in the period given by the following equation:

$$
\text { Balance }_{i}=\text { Investments }_{i}-\text { Withdrawals }_{i} .
$$

Thus, the dependent binary variable is given by the following classification for each individual:

$$
\text { If } \text { Balance }_{i}>0 \text {, the person saved in the last } 12 \text { months (Saver category), }
$$

If Balance $_{i} \leq 0$, the person did not save in the last 12 months (Non-saver category),

Thus, once the "Saver" and "Non-saver" categories are created, the effects of the social security reform on the likelihood of an individual being a saver were estimated, considering the different control group scenarios (Note 8). The standard errors were corrected by White's robust errors and clustered at the State level. 
Some precautions were adopted in the execution of this present study. For example, the effects caused by the reform from the $41^{\text {th }}$ and $47^{\text {th }}$ Constitutional Amendments are ambiguous for public servants who had entered both before 1998 and were young (younger than 25). This is because these workers were "punished" by some of the measures adopted but "benefited" from a transition rule that mitigated the effects of the $20^{\text {th }}$ Amendment of 1998 in relation to the minimum age for retirement. Thus, in the absence of information identifying the date of entry into the public service and since the HBS for 2008-2009 was collected ten years after the $20^{\text {th }} \mathrm{CA}$, it was decided to work only with employees up to 40 years of age at the time of the study (with the same cutoff for the HBS of 2002-2003). Among these public servants, the vast majority either entered after 1998 or entered older than 25 years of age, thus not benefitting from the $47^{\text {th }} \mathrm{CA}$.

The workers who had income from transfers, including pensions and other types of stipends, were also eliminated because these incomes could distort the definitions for the treated group and the control group, as in the case in which a worker linked to the GSSS has a pension linked to the SSSS, for example. Additionally, among the groups not treated, those who had public employees within the same household were excluded, thus avoiding the capture of the indirect effects of the treatment. Finally, people with no income were excluded to keep in the sample only those with income from work.

\section{Results}

Table 1 contains the number of savers and non-savers in each of the HBSs analyzed. When considering the entire sample used, the percentage of savers grew superficially between the 2002/2003 survey and the 2008/2009 survey, from 9.0 to $9.2 \%$.

Of particular note is that the highest percentage of savers is found among public civil servants (treated group) as well as among military employees, although the latter had a low sample size, with only 58 savers in 2002/2003 and 41 savers in 2008/2009.

While the percentage of savers among public servants increased from $12.3 \%$ to $15.3 \%$ between the periods, all of the untreated groups combined showed a decrease from $8.7 \%$ to $8.3 \%$, which indicates opposite trends between the treated and untreated groups. The only control group in which the percentage of savers grew was that of employers or self-employed, increasing from $8.2 \%$ to $9.3 \%$.

Except for the military employees and other groups not treated, the sample is high for all the other groups used, even after applying the filters explained in the methodology. Among those treated, for example, the HBS of 2002-2003 had 3,544 respondents, of which 434 were savers. In 2008/2009, 4,166 public civil servants were interviewed, of which 631 were savers.

Table 1. Number of savers and non-savers and percentage of savers, by year of the HBS and by group

\begin{tabular}{llrrrrrrr}
\hline \multirow{2}{*}{ POF } & \multirow{2}{*}{ CATEGORY } & \multirow{2}{*}{$\begin{array}{c}\text { ENTIRE } \\
\text { SAMPLE }\end{array}$} & \multirow{2}{*}{$\begin{array}{c}\text { TREATED } \\
\text { GROUP }\end{array}$} & $\begin{array}{c}\text { All not } \\
\text { treated }\end{array}$ & $\begin{array}{c}\text { Military } \\
\text { employees }\end{array}$ & $\begin{array}{c}\text { Employers and } \\
\text { self-employed }\end{array}$ & $\begin{array}{c}\text { Employees of } \\
\text { private companies }\end{array}$ & $\begin{array}{c}\text { Others not } \\
\text { treated } \dagger\end{array}$ \\
\hline \multirow{2}{*}{$2002 /$} & Savers & 3.177 & 434 & 2.743 & 58 & 866 & 1.931 & 188 \\
2003 & Non-savers & 31.978 & 3.110 & 28.868 & 331 & 9.644 & 17.571 & 3.837 \\
& \% Savers & $9,0 \%$ & $12,3 \%$ & $8,7 \%$ & $14,8 \%$ & $8,2 \%$ & $9,9 \%$ & $4,7 \%$ \\
\hline \multirow{2}{*}{$2008 /$} & Savers & 3.211 & 631 & 2.580 & 41 & 808 & 1.991 & 76 \\
2009 & Non-savers & 31.874 & 3.485 & 28.389 & 269 & 7.914 & 19.142 & 3.106 \\
& \% Savers & $9,2 \%$ & $15,3 \%$ & $8,3 \%$ & $13,3 \%$ & $9,3 \%$ & $9,4 \%$ & $2,4 \%$ \\
\hline
\end{tabular}

Source: Prepared by the authors, based on the microdata of the POFs of 2002-2003 and 2008-2009.

$\dagger$ Includes domestic employees, temporary employees in rural areas, apprentices or trainees, those not remunerated in assisting a member of the household, and workers in production for self-consumption.

Subsequently, the differences-in-differences model presented in equation 2 of this study was estimated, the marginal effects (Note 9) of which - either from the interaction between the year dummy and the treated group dummy (treatment effect), or from the control variables - are shown in Table 2. In the scenario in which the treated group is compared with all the untreated groups combined, the treatment effect estimated at 0.0288 was shown to be significant at the $1 \%$ level.

Therefore, assuming the identification hypothesis, it is estimated that the social security reform that occurred between the HBSs of 2002-2003 and 2008-2009 added, on average, 2.88 percentage points to the probability of public civil servants being savers. That is, given that the percentage of savers in 2002/2003 was $12.3 \%$ in the treated group, the reform generated growth of $23.4 \%$ in the percentage of savers among civil servants. 
In all the control group scenarios adopted, except when only the military employees were used, the treatment effects found were significant at the $1 \%$ level. In the case in which the civil servants were compared with the untreated group (comprising employees of private companies), the effect found $(0.0215)$ was similar to the effect found $(0.0284)$ in the scenario with employers or self-employed. The highest treatment effect found $(0.0875)$ was when only the "Other workers" was used in the control group.

Finally, in the scenario in which only "Military employees" was used in the control group, the specific estimate found for the treatment effect was high (0.0450). Contradictorily, this last case was the only one in which the results were not significant, which is due to its large standard error because of the small size of the sample formed only by military employees, as shown in Table 1.

Among the controls applied, the marginal effects obtained were shown to be as expected. The two incomes analyzed - both per capita household and individual - showed positive and significant signs for all the "Untreated group" scenarios, as did level of education, which indicates that the higher the income and level of education, the greater is the association with the probability of saving.

In contrast to the results shown in Table 1, which indicate that public civil servants have a greater percentage of savers than the untreated groups, it can be seen in Table 2 that ceteris paribus for the levels of income and education, among other control variables, public servants are less likely to save compared to all the untreated groups combined, and this result is significant at the $10 \%$ level. That is, the higher incidence of savers among the treated group is probably due to their higher level of income and education.

While the sex of the individual and the situation of the household did not show significant associations with the probability of saving, being black showed an inverse association, even for controlled levels of income and education.

Table 2. Estimated marginal effects for the likelihood of saving, as well as respective standard errors, per control group

\begin{tabular}{|c|c|c|c|c|c|}
\hline \multirow[t]{2}{*}{ VARIABLE } & \multicolumn{5}{|c|}{ CONTROL GROUP } \\
\hline & All not treated & $\begin{array}{c}\text { Military } \\
\text { employees }\end{array}$ & $\begin{array}{l}\text { Employers and } \\
\text { self-employed }\end{array}$ & $\begin{array}{c}\text { Employees of private } \\
\text { companies }\end{array}$ & $\begin{array}{l}\text { Others not } \\
\text { treated }^{\dagger \dagger}\end{array}$ \\
\hline Treatment effect $^{\dagger}$ & $\begin{array}{c}0.0288 * * * \\
(0.00942)\end{array}$ & $\begin{array}{c}0.0444 \\
(0.0530)\end{array}$ & $\begin{array}{c}0.0284 * * * \\
(0.0110)\end{array}$ & $\begin{array}{c}\mathbf{0 . 0 2 1 5} * * * \\
(\mathbf{0 . 0 0 7 3 3 )}\end{array}$ & $\begin{array}{c}0.0875 * * * \\
(0.0275)\end{array}$ \\
\hline Post-law & $\begin{array}{c}-0.0388 * * * \\
(0.00695)\end{array}$ & $\begin{array}{l}-0.0616 \\
(0.0500)\end{array}$ & $\begin{array}{c}-0.0422 * * * \\
(0.00902)\end{array}$ & $\begin{array}{c}-0.0343 * * * \\
(0.0101)\end{array}$ & $\begin{array}{c}-0.0886 * * * \\
(0.0169)\end{array}$ \\
\hline Treated group & $\begin{array}{l}-0.0134 * \\
(0.00699)\end{array}$ & $\begin{array}{l}-0.00676 \\
(0.0215)\end{array}$ & $\begin{array}{c}-0.0131 \\
(0.00806)\end{array}$ & $\begin{array}{l}-0.0147 \\
(0.0101)\end{array}$ & $\begin{array}{l}-0.0174 * \\
(0.00942)\end{array}$ \\
\hline $\begin{array}{l}\text { Log of the household income per } \\
\text { capita }(\mathrm{R} \$)\end{array}$ & $\begin{array}{c}0.0243 * * * \\
(0.00453)\end{array}$ & $\begin{array}{c}0.0274 * * * \\
(0.00793)\end{array}$ & $\begin{array}{r}0.0234 * * * \\
(0.00656)\end{array}$ & $\begin{array}{l}0.0276^{* * * *} \\
(0.00339)\end{array}$ & $\begin{array}{c}0.0233 * * * \\
(0.0047)\end{array}$ \\
\hline Log of the individual income $(\mathrm{R} \$)$ & $\begin{array}{l}0.0291 * * * \\
(0.00456)\end{array}$ & $\begin{array}{c}0.0506 * * * \\
(0.0107)\end{array}$ & $\begin{array}{c}0,0416^{* * * *} \\
(0,00825)\end{array}$ & $\begin{array}{c}0.0282 * * * \\
(0.00529)\end{array}$ & $\begin{array}{c}0.0182 * * * \\
(0.00339)\end{array}$ \\
\hline Education & $0.00508 * * *$ & $0.00490 * *$ & $0.00442 * * *$ & $0.00640 * * *$ & $0.00517 * * *$ \\
\hline (in years) & $(0.00078)$ & $(0.00223)$ & $(0.00111)$ & $(0.00092)$ & $(0.00102)$ \\
\hline Age & -0.00021 & -0.00132 & $-0.00107 * *$ & -0.00017 & 0.00106 \\
\hline (in years) & $(0.00037)$ & $(0.00081)$ & $(0.00054)$ & $(0.00048)$ & $(0.00093)$ \\
\hline Sex & 0.00312 & -0.00407 & 0.00032 & -0.00336 & $0.0116^{*}$ \\
\hline$(\mathrm{Man}=1)$ & $(0.00438)$ & $(0.0104)$ & $(0.00647)$ & $(0.00646)$ & $(0.00656)$ \\
\hline Race & $-0.00917 * *$ & $-0.0177 *$ & -0.00854 & -0.00447 & $-0.0152 * * *$ \\
\hline$($ Black=1) & $(0.00447)$ & $(0.0102)$ & $(0.00533)$ & $(0.00705)$ & $(0.00548)$ \\
\hline Situation of the household & $0.0150 *$ & 0.0367 & $0.0159 * *$ & $0.0309 * *$ & 0.0019 \\
\hline (Rural=1) & $(0.00794)$ & $(0.0257)$ & $(0.0070)$ & $(0.0157)$ & $(0.0159)$ \\
\hline
\end{tabular}

Source: Prepared by the authors, based on the microdata of the POFs of 2002-2003 and 2008-2009.

Note 1: Results of the estimation by Equation (3.1).

Note 2: The standard errors were corrected by White's robust errors.

Note 3: The marginal effects of each regressor are estimated by considering the mean of the other independent variables.

$* \mathrm{p}<0.10, * * \mathrm{p}<0.05, * * * \mathrm{p}<0.01$

$\dagger$ This is the interaction between the treated group and the post-law year. It returns the post-reform impact on the public civil servants, in relation to the control group, in terms of the propensity to save.

$\dagger \dagger$ Includes domestic employees, temporary employees in rural areas, apprentices or trainees, those not remunerated in assisting a member of the household, and workers in production for self-consumption. 
These results are an indication that the social security reform implemented by the $41^{\text {th }}$ and $47^{\text {th }}$ Constitutional Amendments generated an increase in the percentage of savers among public servants in Brazil, which is in line with the life cycle hypothesis. It is estimated that the reform generated an increase of approximately three percentage points for the public servants' likelihood of saving, due to changes in the expectations of future benefits.

Therefore, the indications are that in the Brazilian case, the changes in social security laws tend to have a positive effect on the number of savers, with subsequent indirect macroeconomic effects. These results are consistent with the findings in other studies that used the differences-in-differences methodology in countries such as Italy, Mexico, Poland, and Taiwan (see Attanasio \& Brugiavini, 2003; Bottazzi et al., 2006; Sandoval-Hernandez, 2012; Lachowska \& Myck, 2015; and Yang, 2016).

However, it is important to note that the estimated marginal treatment effects shown in the results in Table 2 consider that the other independent variables are at their respective means. Nevertheless, there may be a variation in the treatment effect, depending on the levels of the independent variables.

Thus, the treatment effect was again estimated but for different values of income, education, and age, keeping the other variables independent at their respective means. As shown in Figure 2, while the treatment effect from the reform had practically no effect on low-income public servants, its impact is greater the higher the individual and household incomes per capita. These results were expected because (i) high-income people, on average, are more informed about social security changes; (ii) high-income people have a greater margin for reducing their consumption; and (iii) one of the important items of the reform - the $11 \%$ contribution on values that exceeded the GSSS ceiling - affected only those with a higher income.

Similarly, the higher the level of education is, the greater the treatment effect. These results are consistent with the findings of Lachowska and Myck (2015). Finally, no distinction was found in the treatment effect given the variation in age. However, of particular note, as explained in the methodology, it was decided to keep only 18-40 year olds in the sample in order to eliminate ambiguous cases about the effects of the reform. That is, it is not possible to say whether other reforms, which affected those of all ages, would not have different treatment effects among youths and mature adults.
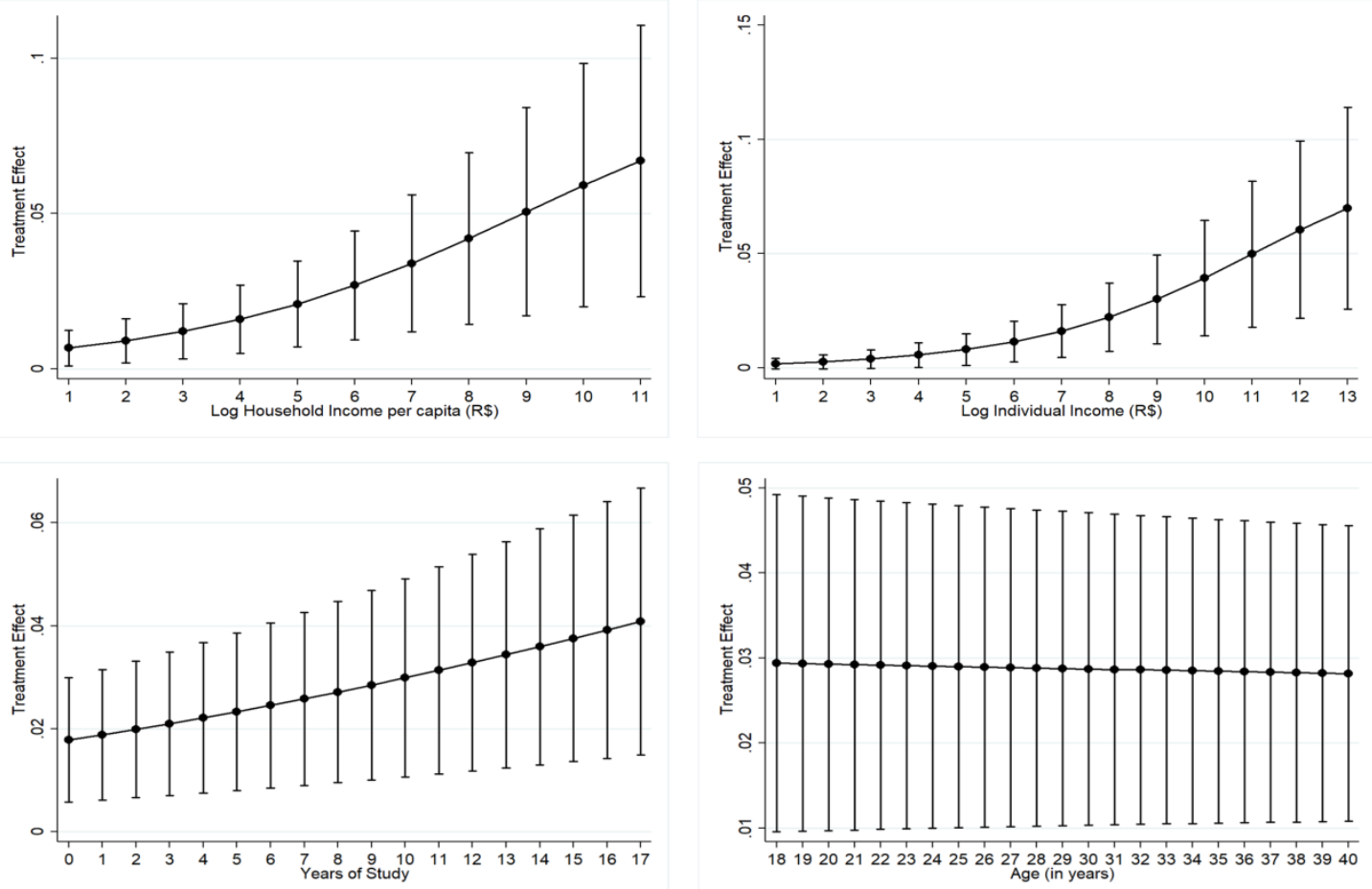

Figure 2. Estimated treatment effects and their respective intervals at $95 \%$ confidence, for different values of annual individual income, monthly household income per capita, years of study, and age.

Source: Prepared by the authors, based on the microdata of the HBSs of 2002-2003 and 2008-2009.

Note. The treatment effects were estimated varying the values of the respective regressors and maintaining the other covariables at the mean values. 
As discussed in the methodology section of this study, the differences-in-differences model has the premise that the only cause for the growth of the difference in the probabilities of saving between the treated group and the control group is due to the treatment effect. Thus, reflecting on other causes - in addition to the effect of the reform - that could contribute to the increase in the difference between the treated group's likelihood of saving and that of the control group, we can highlight the macroeconomic situation. This is because, in times of crisis and unemployment, public servants have their stable jobs; however, other workers do not have this same guarantee, and they may, therefore, modify their likelihood of saving in order to protect themselves against possible dismissal.

Within this context, it is necessary to compare the macroeconomic expectations of the agents as well as the levels of unemployment in the periods in which the HBSs were collected. In fact, the interview periods of both HBSs were at times of macroeconomic instability.

The 2002-2003 HBS was collected between July 2002 and June 2003 - a period of market uncertainty caused by the election of former President Lula in November 2002. Although the "letter to the Brazilian people" - sent by Lula to reduce the uncertainty to unemployment rates, according to the IBGE's National Surveys by Household Sample (Pesquisa Nacional por Amostra de domicílios - PNAD), in 2002 and 2003, the average unemployment rate was $10.2 \%$, compared to $8.4 \%$ between 2008 and 2009. Although it is difficult to say whether this reduction of 1.8 percentage points in the unemployment rate represented a greater perception of stability for the workers linked to the National Social Security Institute in the period of the last HBS, it would be a possible source of bias if this macroeconomic context had had different impacts on the treated group and control group in terms of their behavior related to savings.

However, reinforcing the limitation mentioned above, an indication of robustness for the results found is that the estimated treatment effects for all the different control group scenarios analyzed were positive, in addition to being significant, except in the case of the military employees. However, even in this latter case, the indications are that the non-significance is due to the small size of the sample formed by military employees, given that the specific estimate of the estimated marginal effect was high.

In addition, of particular note is that, in accordance with our literature review, this present study has the merit of being the first to empirically investigate, in the Brazilian context, the effects of a social security reform on private savings. Thus, the results obtained in this study are relevant, particularly if we consider that the discussions on social security changes in Brazil have been a constant theme of the government's agenda.

Since the 2008-2009 HBS, that is, after the analysis period of this study, we can mention the adoption, since 2011, of supplementary social security for the public servants of the Union and of some states in the following years as well as the implementation of rule 85/95 in 2015 for workers linked to the National Social Security Institute; currently, regarding the social security reform that is being debated in the national congress, the final content remains yet unknown. In other words, new changes in Brazilian social security should be constantly discussed, thus increasing the importance of the results found in this present study.

\section{Conclusions}

This present study investigated whether the social security reform implemented in Brazil through the $41^{\text {th }}$ and $47^{\text {th }}$ Constitutional Amendments - which reduced the expectations of benefits by public employees - has led to an increase in the number of savers. As the reform substantially affected only public workers, a differences-in-differences model was used to estimate the marginal effect of the reform on their likelihood of saving. For this purpose, the 2002-2003 and 2008-2009 House Budget Surveys (HBSs) were used, which were collected before and after the reform, respectively.

The results found - which are consistent with the life-cycle hypothesis - are that the reform led to a 2.88 percentage point increase in the probability of public employees making financial investments larger than their withdrawals in the previous 12 months, which represents a $23.4 \%$ increase in the percentage of savers among civil servants.

Even when varying the untreated group used as the control, the results remained positive and, in general, significant. Additionally, of particular note is that the effect of the reform on the probability of saving is higher among individuals with a high level of income and education, with an impact greater than five percentage points for this group. In contrast, among those in the first percentiles of income and education, the estimated effects of the reform on the probability of saving are almost zero.

Although the literature until the 1990s had found ambiguous results for the relationship between social security changes and savings, more recent studies using the differences-in-differences methodology have found results 
similar to those found in this paper. In accordance with our bibliographic review, the present study has the merit of being the first to investigate the effects of social security reforms on private savings for the Brazilian scenario. Thus, the results obtained in this study are relevant, particularly if we consider that the discussions on social security changes in Brazil have been a constant theme of the government's agenda. Certainly this study does not exhaust the theme. In this context of social security reform in Brazil, it is also important to analyze possible effects on other groups of individuals, especially private sector workers.

\section{References}

Amaro, M. N., \& Meneguin, F. B. (2010). Previdência Social e a sustentação das finanças públicas - A atuação do poder legislativo [Social Security and Maintenance of public finances - Performance of Legislative Power]. Revista de Informação Legislativa, 47(187), 91-107.

Ando, A., \& Modigliani, F. (1963). The "life cycle" hypothesis of saving: Aggregate implications and tests. The American Economic Review, 53(1), 55-84.

Attanasio, O. P., \& Brugiavini, A. (2003). Social security and households' saving. The Quarterly Journal of Economics, 118(3), 1075-1119. https://doi.org/10.1162/00335530360698504

Banco, M. (1994). Averting the old age crisis: Policies to protect the old and promote growth. A World Bank Policy Research Report, 1994. https://doi.org/10.1016/S0029-6554(06)80010-2

Bosworth, B., \& Burtless, G. (2004). Pension reform and saving. National Tax Journal, 57(3), 703-727. https://doi.org/10.17310/ntj.2004.3.11

Bottazzi, R., Jappelli, T., \& Padula, M. (2006). Retirement expectations, pension reforms, and their impact on private wealth accumulation. Journal of Public Economics, 90(12), 2187-2212. https://doi.org/10.1016/j.jpubeco.2006.03.005

Brugiavini, A. (1987). Empirical evidence on Wealth Accumulation and the Effects of Pension Wealth: An application to Italian cross-section data. LSE Financial Markets Group, 1987.

Cameron, A. C., \& Trivedi, P. K. (2005). Microeconometrics: methods and applications. Cambridge university press. https://doi.org/10.1017/CBO9780511811241

Feldstein, M. (1974). Social security, induced retirement, and aggregate capital accumulation. Journal of Political Economy, 82(5), 905-926. https://doi.org/10.3386/w0579

Friedman, M. (1957). The permanent income hypothesis. In A theory of the Consumption Function (pp. 20-37). Princeton University Press.

Gale, W. G. (1998). The effects of pensions on household wealth: A reevaluation of theory and evidence. Journal of Political Economy, 106(4), 706-723. https://doi.org/10.1086/250027

Giambiagi, F., \& Além, A. C. (2008). Finanças públicas: teoria e prática no Brasil. Elsevier Brasil.

Heller, P. S. (1989). Aging, Savings, and Pensions in the Group of Seven Countries: 1980-2025. Journal of Public Policy, 9(2), 127-155. https://doi.org/10.1017/S0143814X00008096

Holzmann, R. (1997). Fiscal alternatives of moving from unfunded to funded pensions. Working Paper Awp 5.2. OCDE. https://doi.org/10.1787/18151949

Hubbard, R. G. (1986). Pension wealth and individual saving: Some new evidence. Journal of Money, Credit and Banking, 18(2), 167-178. https://doi.org/10.2307/1992200

IBGE. (2004). Instituto Brasileiro de Geografia e Estatística. Microdados da Pesquisa de Orçamento Familiar 2002-2003 [2002-2003 Family Budget Survey Microdata]. Rio de Janeiro: Instituto Brasileiro de Geografia e Estatística.

IBGE. (2011). Instituto Brasileiro de Geografia e Estatística. Microdados da Pesquisa de Orçamento Familiar 2008-2009 [2008-2009 Family Budget Survey Microdata]. Rio de Janeiro: Instituto Brasileiro de Geografia e Estatística.

Jappelli, T. (1995). Does social security reduce the accumulation of private wealth? Evidence from Italian survey data. Ricerche Economiche, 49(1), 1-31. https://doi.org/10.1016/0035-5054(95)90008-X

King, M. A., \& Dicks-Mireaux, L. (1982). Asset Holdings and the Life-Cycle. The Economic Journal, 92(366), 247-267. https://doi.org/10.3386/w0614

Lachowska, M., \& Myck, M. (2015). The effect of public pension wealth on saving and expenditure. IZA 
Discussion Paper Series DP No. 8895. https://doi.org/10.17848/wp15-223

Mackenzie, G. A., Gerson, P. R., \& Cuevas, A. A. (1997). Reforma da previdência pública aumenta a poupança? [Does reform of social security increase savings?] Finanças \& Desenvolvimento, 17(4), 44-47. https://doi.org/10.1590/0101-31572017v37n03a09

Mesquita, R. A., \& Balbinoto, N. G. (2013). Produtividade, Demografia e Sustentabilidade da Previdência Social [Productivity, Demographics and Sustainability of Social Security]. Revista EconomiA, 14(1B), 389-427.

Modigliani, F., \& Ando, A. K. (1957). Tests of the life cycle hypothesis of savings: comments and suggestions. $\begin{array}{lllll}\text { Oxford Bulletin of Economics and Statistics, } & \text { 19(2), }\end{array}$ https://doi.org/10.1111/j.1468-0084.1957.mp19002002.x

Munnell, A. H. (1974). The impact of social security on personal savings. National Tax Journal, 27(4), 553-567. https://doi.org/10.1016/0165-1765(88)90014-6

Munnell, A. H. (1976). Private pensions and savings: new evidence. The Journal of Political Economy, 84(5), 1013-1032. https://doi.org/10.1086/260494

Puhani, P. A. (2012). The treatment effect, the cross difference, and the interaction term in nonlinear $\begin{array}{lllll}\text { "difference-in-differences" } & \text { models. }\end{array}$ https://doi.org/10.1016/j.econlet.2011.11.025

Rondanelli, E. (1996). Chilean pension reform and its impacts on saving. Universidad Gabriela Mistral: Instituto de Economia. Work presented at the VIII Seminário Regional de Política Fiscal. Santiago de Chile: Cepal.

Samwick, A. A. (2000). Is pension reform conducive to higher saving? Review of Economics and Statistics, 82(2), 264-272. https://doi.org/10.1162/003465300558777

Sandoval-Hernandez, J. (2012). The Impact of Pension Reforms on Mexican Household Saving. College of Charleston, Charleston, SC. Working Paper.

Schmidt-Hebbel, K. (1999). Does Pension Reform Really Spur Productivity, Saving and Growth? Banco Central de Chile, Gerencia de Investigación Económica, Departamento Publicaciones.

Yang, T. T. (2016). The Effect of Workplace Pensions on Household Saving: Evidence from a Natural Experiment in Taiwan. Institute of Economics Academia Sinica, Working Paper. https://doi.org/10.1111/jori.12254

\section{Notes}

Note 1. The term "pension wealth" is commonly used in the literature to refer to the expectations of future pension benefits discounted to present value.

Note 2. With the exception of the municipalities that opted to link their employees to the GSSS.

Note 3 . Added the contribution of $20 \%$ of the time remaining to achieve the necessary contribution time, and stipulated the minimum age of 53 years for men and 48 years for women.

Note 4. It is important to emphasize that the 2002-2003 HBS was conducted in the period from July 2002 to June 2003, whereas the $41^{\text {th }}$ CA was enacted in December 2003; that is, after the IBGE's survey.

Note 5. Includes domestic employees, temporary employees in rural areas, apprentices or trainees, those not emunerated in assisting a member of the household, and workers in production for self-consumption.

Note 6. Puhani (2012) showed that the coefficients of the differences-in-differences models are valid in specifications of non-linear models such as PROBIT, LOGIT, and TOBIT.

Note 7. Estimates by Ordinary Least Squares (OLS) were also performed.

Note 8. The HBS does not involve interviewing the same individuals in the different periods, which restricts the use of specific panel methodologies such as Propensity Score Matching, for example.

Note 9. In the results shown in this work, the necessary transformations on the coefficients had already been done, thus working with the estimated marginal effects of each regressor for the probability of saving. For the estimates, it is considered that the other independent variables are at their mean values.

\section{Copyrights}

Copyright for this article is retained by the author(s), with first publication rights granted to the journal.

This is an open-access article distributed under the terms and conditions of the Creative Commons Attribution license (http://creativecommons.org/licenses/by/4.0/). 